\title{
Study of the Electrochemical Behavior of High Voltage Vanadium-Metal Hydride Hybrid Semi-Flow Battery
}

\author{
Guo-Ming Weng, Chi-Ying Vanessa Li $\uparrow$ and Kwong-Yu Chan * \\ Department of Chemistry, The University of Hong Kong, Pokfulam Road, Hong Kong \\ $\dagger *$ Corresponding Author Tel: +(852) 2859 7917, Fax: +(852) 2857 1586, \\ E-mail: †cyvli@hku.hk; * hrsccky@hku.hk
}

\begin{abstract}
A vanadium-MH rechargeable semi-flow battery hybridizing the $\mathrm{V}^{4+} / \mathrm{V}^{5+}$ redox couple (positive) with the metal hydride (negative) was investigated to increase the cell voltage greatly and eliminate the problems of $\mathrm{V}^{2+}$ oxidation. The experimental open circuit voltage of $1.86 \mathrm{~V}$ and operating voltage of $1.65 \mathrm{~V}$ for this hybrid battery were obtained, very high values among all rechargeable flow batteries. The system demonstrated superior stability, reversibility, and efficiencies in coulomb (97\%), energy (81.3\%), and voltage $(83.8 \%)$.
\end{abstract}

\section{Introduction}

Flow batteries [1-4] are actively studied for storing electricity, particularly intermittently generated from solar, wind, and other renewable sources [5]. The all-vanadium redox flow (VRF) battery $[6,7]$ is one of the most promising flow batteries, but still requiring improvements and development [8].

Theoretical specific energy of VRF battery is $60.5 \mathrm{Wh} / \mathrm{kg}$. The VRF battery (as shown in Scheme 1) is acidic and has a positive $\mathrm{V}^{4+} / \mathrm{V}^{5+}$ electrolyte at a standard potential of $1.0 \mathrm{~V}$ coupled with a negative electrolyte $\mathrm{V}^{2+} / \mathrm{V}^{3+}$ at $-0.26 \mathrm{~V}$, giving a theoretical cell voltage of $1.26 \mathrm{~V}$.

$$
\begin{array}{cc}
\text { Positive: } \mathrm{VO}_{2}^{+}+2 \mathrm{H}^{+}+\mathrm{e}^{-} \underset{\text { Charge }}{\stackrel{\text { Discharge }}{\rightleftarrows}} \mathrm{VO}^{2+}+\mathrm{H}_{2} \mathrm{O} & \left(E^{o}=1.00 \mathrm{~V}\right) \\
\text { Negative: } \mathrm{V}^{2+} \underset{\text { Charge }}{\stackrel{\text { Discharge }}{\rightleftarrows}} \mathrm{V}^{3+}+\mathrm{e}^{-} & \left(E^{o}=-0.26 \mathrm{~V}\right)
\end{array}
$$

Scheme 1. Electrochemistry of VRF.

Serious attempts were made to improve vanadium flow battery technology by alternative pairing of negative and positive electrode/electrolyte reactions into a hybrid cell [9-14]. Skyllas-Kazacos et al. [9] reported a hybrid Vanadium- $\mathrm{O}_{2}$ redox fuel cell, thus eliminating the mass of the positive side as oxygen can be freely stored in air. The reported specific energy is $>40 \mathrm{Wh} / \mathrm{kg}$, about 1.6 times the practical specific energy of conventional VRF battery, whereas the reported open circuit voltage (OCV) was kept in 
the range of 1.10 to $1.24 \mathrm{~V}$. But the oxygen reaction is highly irreversible and the absence of a good bi-functional electrocatalyst leads to low voltage efficiency. A vanadium chloride/polyhalide redox flow battery proposed by the same group [14] increased the specific energy significantly as a consequence of higher vanadium concentration can be used in the presence of mixed electrolyte, and with an experimental OCV of $1.3 \mathrm{~V}$. Crossover of ions through the membrane was reduced during operation. Both attempts give similar OCV to that of the conventional VRF battery.

With the concept of $\mathrm{pH}$ differential between an alkaline negative electrode and acidic positive electrode, higher cell voltages have been demonstrated for $\mathrm{H}_{2}-\mathrm{O}_{2}$ fuel cells [1517] and $\mathrm{PbO}_{2} / \mathrm{PbSO}_{4}-\mathrm{MH}_{\mathrm{x}} / \mathrm{MH}_{\mathrm{x}-1}$ rechargeable batteries [17-20]. A bipolar membrane was used to provide the ionic contact as well as barrier in the $\mathrm{pH}$ differential cells $[16,17$, $19,20]$. The lead acid/MH system reported a stable operating voltage with repeated charge/discharge cycles at $2.6 \mathrm{~V}(30 \%$ and $86 \%$ increase from individual lead-acid and $\mathrm{NiMH}$ batteries). The higher voltage and increased capacity is a result of the extra energy store/released in acid-alkaline neutralization corresponding to $\Delta \mathrm{G}^{\mathrm{o}}=-79.85 \mathrm{~kJ} / \mathrm{mol}[17$, $18]$.

It is conceptually attractive to increase the voltage of vanadium flow battery with introduction of a $\mathrm{pH}$ differential by coupling the positive $\mathrm{V}^{4+} / \mathrm{V}^{5+}$ with a negative alkaline electrode/electrolyte. Moreover, the problem of $\mathrm{V}^{2+}$ oxidation can be eliminated. In this paper, we combine the advantages of the vanadium redox flow battery and the acid/alkaline hybrid battery, and demonstrate a novel semi-flow vanadium-metal hydride (V-MH) hybrid rechargeable battery. Additional neutralization energy can be stored in the electrolyte and liquid flow minimizes fouling and enhances the function of the ionic interfaces. In principle, this hybrid battery system of $\mathrm{V}^{4+} / \mathrm{V}^{5+}$ and metal hydride can deliver an overall cell capacity of $111 \mathrm{mAh} / \mathrm{g}$, cell voltage of $1.8 \mathrm{~V}$, and specific energy of $200 \mathrm{Wh} / \mathrm{kg}$, much higher than that of conventional VRF battery. This paper reports the electrochemical properties of the new hybrid flow battery, cell voltage, electrode overpotentials, and voltage across membrane are monitored during idle, charge and discharge. The electrochemistry of this V-MH flow battery is shown in Scheme 2.

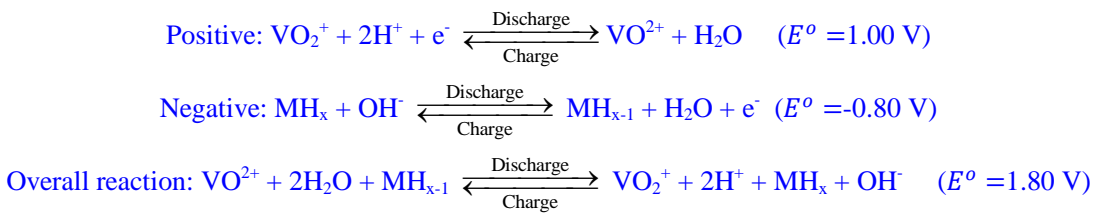

Scheme 2. Electrochemistry of V-MH. 


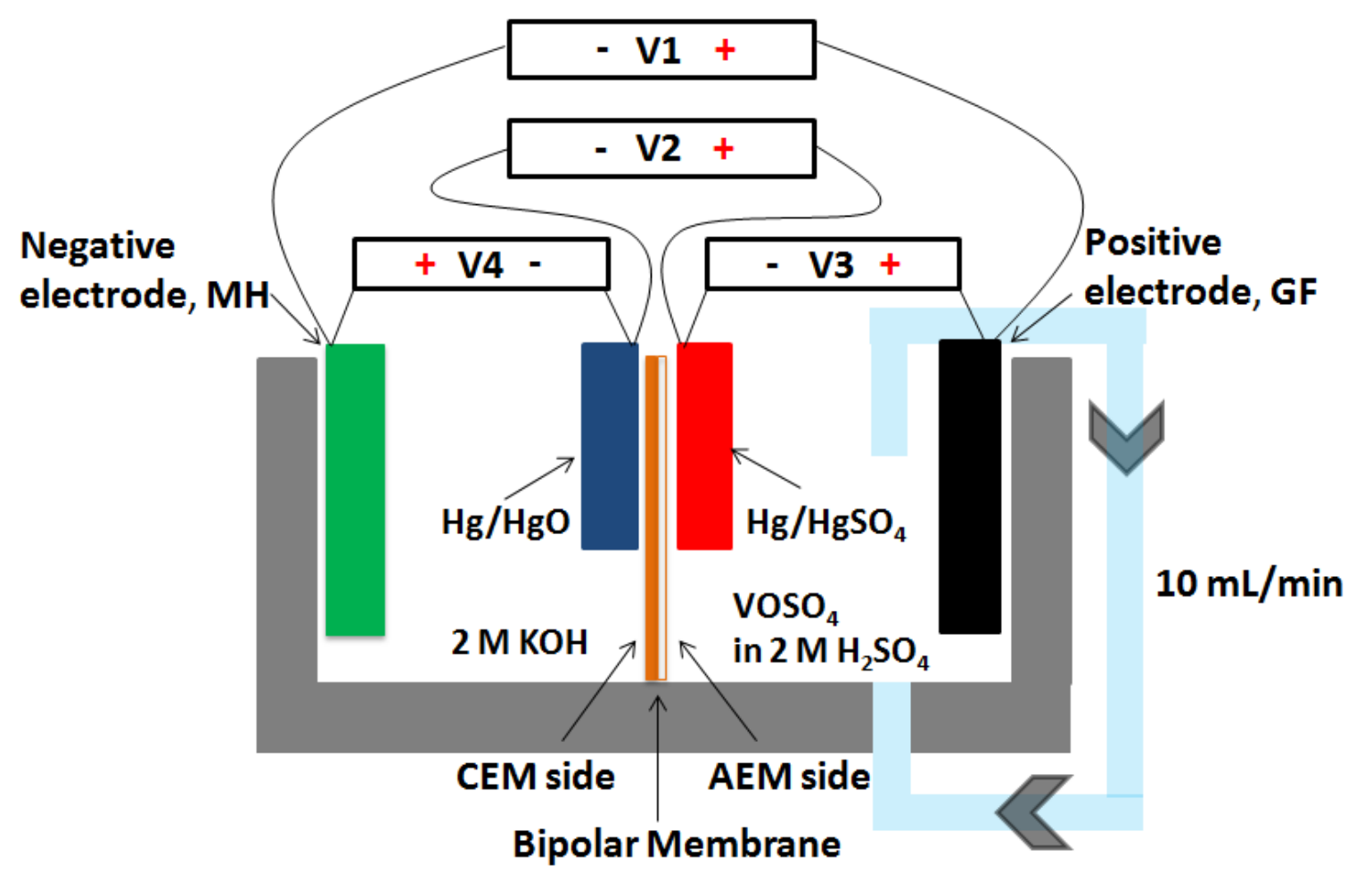

Fig. 1. Schematic drawing of the V-MH hybrid system with positive electrolyte flow. V1: Potential difference between GF electrode and $\mathrm{MH}_{\mathrm{x}} / \mathrm{MH}_{\mathrm{x}-1}$ electrode or overall cell potential. V1 $=\phi_{\text {positive }}-\phi_{\text {negative }}$; V2: Potential across bipolar membrane or potential difference between reference electrodes $\mathrm{Hg} / \mathrm{Hg}_{2} \mathrm{SO}_{4}$ and $\mathrm{Hg} / \mathrm{HgO} . \mathrm{V} 2=\phi_{\mathrm{Hg} / \mathrm{Hg} 2 \mathrm{SO} 4}$ $\phi_{\mathrm{Hg} / \mathrm{HgO}}$ (Here the reference electrode $\mathrm{Hg} / \mathrm{HgO}$ in alkaline solution is arbitrarily defined as reference electrode as it is immersed into the negative chamber); V3: Potential difference between graphite felt (GF) electrode (positive electrode) and reference electrode $\left(\mathrm{Hg} / \mathrm{Hg}_{2} \mathrm{SO}_{4}\right) . \mathrm{V} 3=\phi_{\text {positive }}-\phi_{\mathrm{Hg} / \mathrm{Hg} 2 \mathrm{SO} 4} ; \mathrm{V} 4$ : Potential difference between $\mathrm{MH}_{\mathrm{x}} / \mathrm{MH}_{\mathrm{x}-1}$ electrode (negative electrode) and reference electrode $(\mathrm{Hg} / \mathrm{HgO}) . \mathrm{V} 4=\phi_{\text {negative }}-\phi_{\mathrm{Hg} / \mathrm{HgO}}$.

\section{Experimental and Results}

\section{Electrode preparation}

Commercial graphite felt (Shenhe Carbon Fiber Materials Co. Ltd., Liaoning, China) was used as positive electrode and had an active surface area of around $9 \mathrm{~cm}^{2}$ with a thickness of $5 \mathrm{~mm}$, these graphite felt were pre-treated before use. The pre-treatment as follows: the graphite felt (GF) was soaked in $95 \%$ (wt $\%) \mathrm{H}_{2} \mathrm{SO}_{4}$ at $50{ }^{\circ} \mathrm{C}$ for $2 \mathrm{~h}$. Rinsed it with DI water until the effluent $\mathrm{pH}$ is near neutral and then heat treated at $60{ }^{\circ} \mathrm{C}$ for $2 \mathrm{~h}$ to improve its electrochemical activity and hydrophilicity. The negative $\mathrm{MH}_{\mathrm{x}}$ electrode was prepared by $1 \mathrm{~g}$ of $\mathrm{LaNi}_{5}$ based metal-hydride alloy powder extracted from a commercial GP-2700 AA battery. The $\mathrm{LaNi}_{5}$ based powder was mixed with $50 \mathrm{mg} \mathrm{XC}$ - 
72 vulcan carbon $\left(4.5 \mathrm{wt} \%\right.$ ), pasted and pressed on nickel foam. The active area of $\mathrm{MH}_{\mathrm{x}}$ electrode was around $9 \mathrm{~cm}^{2}$.

The initial $0.064 \mathrm{~mol} / \mathrm{L}$ positive $\mathrm{VOSO}_{4}$ electrolyte was prepared from dissolving $0.274 \mathrm{~g} \mathrm{VOSO}_{4} \cdot \mathrm{nH}_{2} \mathrm{O}$ (Dieckmann Chemical Industrial Co. Ltd., Hong Kong, $\mathrm{n}=2.85$ according to thermogravimetric analysis) in $20 \mathrm{~mL} 2 \mathrm{~mol} / \mathrm{L} \mathrm{H}_{2} \mathrm{SO}_{4}$ solution, respectively.

\section{$\underline{\text { Vanadium-MH flow battery design }}$}

The hybrid battery had two compartments (See Fig. 1). The acid chamber contained a graphite felt positive electrode immersed in $0.064 \mathrm{~mol} / \mathrm{L}$ positive $\mathrm{VOSO}_{4}$ electrolyte in 2 $\mathrm{mol} / \mathrm{L} \mathrm{H}_{2} \mathrm{SO}_{4}$ solution, while the alkaline chamber contained a $\mathrm{MH}_{\mathrm{x}}$ negative plate inserted in $20 \mathrm{~mL} 2 \mathrm{~mol} / \mathrm{L} \mathrm{KOH}$ aqueous solution. The two chambers were separated by a bipolar membrane (Membrane International Inc., USA). The active area of the bipolar membrane is $20 \mathrm{~cm}^{2}$ with a dimension of $40 \mathrm{~mm}(\mathrm{~L}) \times 50 \mathrm{~mm}(\mathrm{H})$. The membrane was preconditioned by immersing into $5 \mathrm{wt} \% \mathrm{NaCl}$ solution over night before use. The volume of each acid and alkaline electrolyte was about $20 \mathrm{~mL}$ in a chamber of dimensions $46 \mathrm{~mm}(\mathrm{~L}) \times 68 \mathrm{~mm}(\mathrm{H}) \times 10 \mathrm{~mm}(\mathrm{~W})$. The flow rate was fixed at $10 \mathrm{~mL} / \mathrm{min}$ for the $\mathrm{VOSO}_{4}$ electrolyte in the positive chamber of Vanadium-MH system.

\section{Electrochemical tests and cell performance}

All electrochemical performance tests were carried out at room temperature. Galvanostatic charge and discharge measurements were carried out with Voltalab PGZ301. $\mathrm{Hg} / \mathrm{HgSO}_{4}$ (filling solution: $2 \mathrm{~mol} / \mathrm{L} \mathrm{H}_{2} \mathrm{SO}_{4}$ ) and $\mathrm{Hg} / \mathrm{HgO}$ (filling solution: 2 $\mathrm{mol} / \mathrm{L} \mathrm{KOH}$ ) are employed as reference electrodes in the acid and alkaline chambers of the Vanadium-MH system, respectively. The positive electrolyte was circulated in the positive chamber through Phar-Med NSF-51 tube by using Watson-Marlow Bredel's 323 peristaltic pump at $10 \mathrm{~mL} / \mathrm{min}$. The hybrid system was left idle for 1 hour, and then charge and discharge at constant current of $9 \mathrm{~mA}\left(1 \mathrm{~mA} / \mathrm{cm}^{2}\right)$ in all runs. The cut-off voltage is $2.0 \mathrm{~V}-1.6 \mathrm{~V}$. During idle and operation, the overall cell potential (V1), the potential across the membrane (V2), and the electrode potential versus corresponding reference electrode: $\mathrm{Hg} / \mathrm{HgSO}_{4}(\mathrm{~V} 3)$ and $\mathrm{Hg} / \mathrm{HgO}(\mathrm{V} 4)$ were recorded by National Instrument PCI-6221 Data Acquisition (as shown in Fig. 1).

Performance of individual components of the V-MH cell can be evaluated from the four voltage profiles V1-V4, as shown in Fig. 2 for 5 charge and discharge cycles. For the overall cell voltage, $\mathrm{V} 1$, the charge and discharge plateaus are stable throughout the 5 cycles at c.a. $1.86 \mathrm{~V}$, and $1.65 \mathrm{~V}$, respectively.

As shown in Fig. 2, the shape of the charge/discharge curves (V1) resembles that of the positive electrodes (V3), whilst the voltage loss between charge and discharge of the $\mathrm{MH}$ negative electrode (V4) remains small. The present setup of V-MH is therefore limited by the positive side. Throughout the cycles, the voltage loss across the membrane 
(V2) remains stable at 0.4 to $0.6 \mathrm{~V}$, indicating a steady and reversible process of ionic transport.

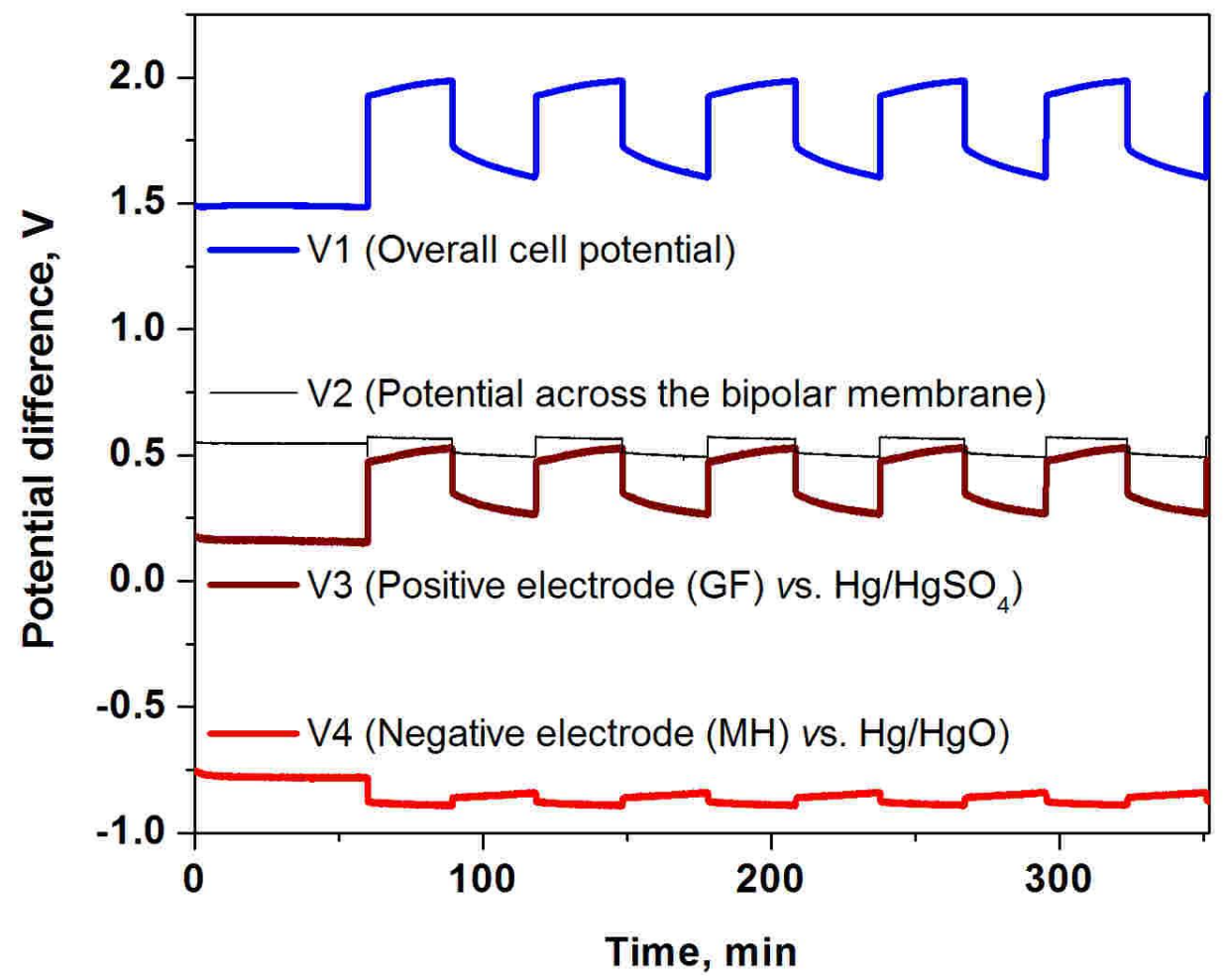

Fig. 2.5 charge and discharge cycles $\left(1^{\text {st }}-5^{\text {th }}\right)$ of V-MH battery. V1: Potential difference between GF electrode and $\mathrm{MH}_{\mathrm{x}} / \mathrm{MH}_{\mathrm{x}-1}$ electrode or overall cell potential. $\mathrm{V} 1=\phi_{\text {positive }}$ $\phi_{\text {negative; }}$ V2: Potential across bipolar membrane or potential difference between reference electrodes $\mathrm{Hg} / \mathrm{Hg}_{2} \mathrm{SO}_{4}$ and $\mathrm{Hg} / \mathrm{HgO} . \mathrm{V} 2=\phi_{\mathrm{Hg} / \mathrm{Hg} 2 \mathrm{SO} 4}-\phi_{\mathrm{Hg} / \mathrm{HgO}}$ (Here the reference electrode $\mathrm{Hg} / \mathrm{HgO}$ in alkaline solution is arbitrarily defined as reference electrode as it is immersed into the negative chamber); V3: Potential difference between graphite felt (GF) electrode (positive electrode) and reference electrode $\left(\mathrm{Hg} / \mathrm{Hg}_{2} \mathrm{SO}_{4}\right) . \mathrm{V} 3=\phi_{\text {positive }}$ $\phi_{\mathrm{Hg} / \mathrm{Hg} 2 \mathrm{SO} 4}$; V4: Potential difference between $\mathrm{MH}_{\mathrm{x}} / \mathrm{MH}_{\mathrm{x}-1}$ electrode (negative electrode) and reference electrode $(\mathrm{Hg} / \mathrm{HgO}) . \mathrm{V} 4=\phi_{\text {negative }}-\phi_{\mathrm{Hg} / \mathrm{HgO}}$.

Efficiencies of the V-MH battery are analysed from the voltage profiles. In the first cycle, the overall cell voltage V1 takes around 29.4 minutes to reach $2.00 \mathrm{~V}$. Then it discharges with a plateau of $1.65 \mathrm{~V}$ for c.a. 29 minutes until the $1.6 \mathrm{~V}$ cut-off, with a charge efficiency of $98.6 \%$. In the 5th cycle, the charge efficiency maintained with an operating voltage $\sim 1.65 \mathrm{~V}$. As shown in the matching V1 and V3 curves, which indicates the positive side mainly determines the overall cell performance in this case.

Voltage efficiency, defined as (averaged discharge voltage)/(averaged charge voltage), is $83.8 \%$ at the end of the 5 th cycle. Corresponding energy efficiency is $81.3 \%$. These 
values are much higher than those of the VRF battery, as shown in Table 1. One disadvantage of VRF battery over other conventional batteries is its low specific energy. With this semi-flow V-MH battery, the theoretical specific energy can be increased up to $200 \mathrm{Wh} / \mathrm{kg}, 3.5$ times that of VRF battery. In addition to a higher discharge voltage, the efficiency in voltage, coulombic, and energy for V-MH battery improved. Specifically, the voltage efficiency is $83.8 \%$ compared to $62-73 \%$ for VRF, while the charge efficiency was maintained at $97 \%$. Higher energy efficiency $81.3 \%$ was obtained for V$\mathrm{MH}$ battery, compared to $66-75 \%$ for VRF, representing an increase of $>8 \%$.

Table 1. Comparison of V-MH and VRF batteries in terms of average voltage, coulomb, and energy efficiencies.

\begin{tabular}{ccccc} 
Battery type & $\begin{array}{l}\text { Nominal } \\
\text { voltage, V }\end{array}$ & $\begin{array}{l}\text { Voltage } \\
\text { efficiency }\end{array}$ & $\begin{array}{l}\text { Coulombic } \% \\
\text { efficiency }\end{array}$, \% & $\begin{array}{l}\text { Energy } \\
\text { efficiency }^{\mathrm{d}}, \%\end{array}$ \\
\hline V-MH & 1.65 & 83.8 & 97 & 81.3 \\
VRF[8] & 1.25 & $62-73$ & $80-98$ & $66-75$ \\
\hline
\end{tabular}

${ }^{\mathrm{b}}$ Voltage efficiency: $\eta_{V}=V_{\text {discharge }} / V_{\text {charge }}$

${ }^{\mathrm{c}}$ Coulomb/charge efficiency: $\eta_{c}=Q_{\text {discharge }} / Q_{\text {charge }}=\left(I t_{\text {discharge }}\right) /\left(I_{\text {charge }}\right)$

${ }^{\mathrm{d}}$ Energy efficiency: $\eta_{P}=E_{\text {discharge }} / E_{\text {charge }}=\left(V_{\text {discharge }} I t_{\text {discharge }}\right) /\left(V_{\text {charge }} I_{\text {charge }}\right)$

Improvement over the preliminary results of the lab-scale V-MH system are expected with optimization in electrolyte flow rates, concentrations, electrodes material, membrane thickness, or other cell and operation parameters. The power and specific energy of the $\mathrm{V}-\mathrm{MH}$ hybrid battery can be further increased with scale-up. Depends on the application, the hybrid system can provide further specific improvement over existing options of VRF, lead acid, or MH systems.

\section{Conclusions}

A novel semi-flow Vanadium-Metal Hydride (V-MH) system $\left(200 \mathrm{Wh} \mathrm{kg}^{-1}\right.$ ) with 3.5 times higher theoretical specific energy than that of the conventional all vanadium redox flow battery $\left(60.5 \mathrm{Wh} \mathrm{kg}^{-1}\right)$ was reported. Hybridizing the $\mathrm{V}^{4+} / \mathrm{V}^{5+}$ couple with metal hydride eliminates the problem of $\mathrm{V}^{2+}$ oxidation as in VRF battery. The average voltage of the Vanadium-MH battery system during discharge is around $1.65 \mathrm{~V}$, which is higher than that of individual all vanadium redox flow battery $(1.2-1.4 \mathrm{~V})$ and $\mathrm{NiMH}_{\mathrm{x}}$ battery $(1.25-1.35 \mathrm{~V})$. The Vanadium-MH battery system has good reversibility and efficiency in voltage $(83.8 \%)$, coulombic $(97 \%)$ and energy $(81.3 \%)$, which is critical for its potential application.

\section{Acknowledgments}

The authors would like to acknowledge Prof. Fung in the department of Physics, The University of Hong Kong for providing PCI data acquisition equipments (National Instrument). This research is supported by Research Grants Council of Hong Kong (GRF HKU 700209P and GRF HKU 700210P), University of Hong Kong SRT, The University Development Fund on the Initiative of Clean Energy and Environment. 


\section{References}

1. L. H. Thaller, NASA TMX-71540 (1974).

2. L. H. Thaller, U.S. Patent 3,996,064 (1974).

3. R. F. Savinell, C. C. Liu, R. T. Galasco, S. H. Chiang and J. F. Coetzee, J. Electrochem. Soc., 126, 357 (1979).

4. M. Bartolozzi, J. Power Sources, 27, 219 (1989).

5. L. Joerissen, J. Garche, C. Fabjan and G. Tomazic, J. Power Sources, 127, 98 (2004).

6. M. Skyllas-Kazacos and F. Grossmith, J. Electrochem. Soc., 134, 2950 (1987).

7. M. Skyllas-Kazacos, M. Rychick and R. G. Robins, US Patent 4,786,567 (1988).

8. C. Ponce-de-León, A. Frías-Ferrer, J. González-García, D. A. Szánto and F. C. Walsh, J. Power Sources, 160, 716 (2006).

9. C. Menictas and M. Skyllas-Kazacos, J. Appl. Electrochem., 41, 1223 (2011).

10. L. Y. Li, S. W. Kim, W. Wang, M. Vijayakumar, Z. M. Nie, B. W. Chen, J. L. Zhang, G. G. Xia, J. Z. Hu, G. Graff, J. Liu and Z. G. Yang, Adv. Energy Mater., 1, 394 (2011).

11. S. Liu, G. L. Pan, N. F. Yan and X. P. Gao, Energy Environ. Sci., 3, 1732 (2010).

12. J. P. Zheng, P. Andrei, M. Hendrickson and E. J. Plichta, J. Electrochem. Society, 158, A43 (2011).

13. H. S. Zhou, Y. G. Wang, H. Q. Li and P. He, ChemSusChem, 3, 1009 (2010).

14. M. Skyllas-Kazacos, J. Power Sources, 124, 299 (2003).

15. J. L. Cohen, D. J. Volpe, D. A. Westly, A. Pechenik and H. D. Abruña, Langmuir, 21, 3544 (2005).

16. S. A. Cheng and K. Y. Chan, US Patent 7,344,801 (2008).

17. S. Cheng and K. Y. Chan, ECS Transactions, 25, 213 (2010).

18. H. Q. Li, G. M. Weng, C. Y. V. Li and K. Y. Chan, Electrochim. Acta, 56, 9420 (2011).

19. G. M. Weng, C. Y. V. Li and K. Y. Chan, ECS Transactions, 41, 133 (2012).

20. G. M. Weng, C. Y. V. Li and K. Y. Chan, Meet. Abstra. Electrochem. Soc., MA2012-02, 372 (2012).

21. J. D. Dunlop, G. M. Rao and T. Y. Yi, NASA Handbook for Nickel-Hydrogen Batteries, NASA Reference Publication 1314 (1993).

22. L. H. Thaller and A. H. Zimmerman, NASA/TP-2003-211905 (2003). 


\section{Figure Captions}

Fig. 1. Schematic drawing of the V-MH hybrid system with positive electrolyte flow. V1: Potential difference between GF electrode and $\mathrm{MH}_{\mathrm{x}} / \mathrm{MH}_{\mathrm{x}-1}$ electrode or overall cell potential. V1= $\phi$ positive - $\phi$ negative; V2: Potential across bipolar membrane or potential difference between reference electrodes $\mathrm{Hg} / \mathrm{Hg}_{2} \mathrm{SO}_{4}$ and $\mathrm{Hg} / \mathrm{HgO} . \mathrm{V} 2=\phi \mathrm{Hg} / \mathrm{Hg}_{2} \mathrm{SO}_{4}-$ $\phi \mathrm{Hg} / \mathrm{HgO}$ (Here the reference electrode $\mathrm{Hg} / \mathrm{HgO}$ in alkaline solution is arbitrarily defined as reference electrode as it is immersed into the negative chamber); V3: Potential difference between graphite felt (GF) electrode (positive electrode) and reference electrode $\left(\mathrm{Hg} / \mathrm{Hg}_{2} \mathrm{SO}_{4}\right) . \mathrm{V} 3=\phi$ positive $-\phi \mathrm{Hg} / \mathrm{Hg}_{2} \mathrm{SO}_{4} ; \mathrm{V} 4$ : Potential difference between $\mathrm{MH}_{\mathrm{x}} / \mathrm{MH}_{\mathrm{x}-1}$ electrode (negative electrode) and reference electrode $(\mathrm{Hg} / \mathrm{HgO}) . \mathrm{V} 4=$ $\phi$ negative - $\phi \mathrm{Hg} / \mathrm{HgO}$.

Fig. 2.5 charge and discharge cycles $\left(1^{\text {st }}-10^{\text {th }}\right)$ of V-MH battery. V1: Potential difference between GF electrode and $\mathrm{MH}_{\mathrm{x}} / \mathrm{MH}_{\mathrm{x}-1}$ electrode or overall cell potential. V1= $\phi$ positive $\phi$ negative; V2: Potential across bipolar membrane or potential difference between reference electrodes $\mathrm{Hg} / \mathrm{Hg}_{2} \mathrm{SO}_{4}$ and $\mathrm{Hg} / \mathrm{HgO} . \mathrm{V} 2=\phi_{\mathrm{Hg} / \mathrm{Hg} 2 \mathrm{SO} 4}-\phi \mathrm{Hg} / \mathrm{HgO}$ (Here the reference electrode $\mathrm{Hg} / \mathrm{HgO}$ in alkaline solution is arbitrarily defined as reference electrode as it is immersed into the negative chamber); V3: Potential difference between graphite felt (GF) electrode (positive electrode) and reference electrode $\left(\mathrm{Hg} / \mathrm{Hg}_{2} \mathrm{SO}_{4}\right)$. $\mathrm{V} 3=\phi$ positive $-\phi \mathrm{Hg} / \mathrm{Hg}_{2} \mathrm{SO}_{4}$; V4: Potential difference between $\mathrm{MH}_{\mathrm{x}} / \mathrm{MH}_{\mathrm{x}-1}$ electrode (negative electrode) and reference electrode $(\mathrm{Hg} / \mathrm{HgO}) . \mathrm{V} 4=\phi$ negative $-\phi \mathrm{Hg} / \mathrm{HgO}$. 


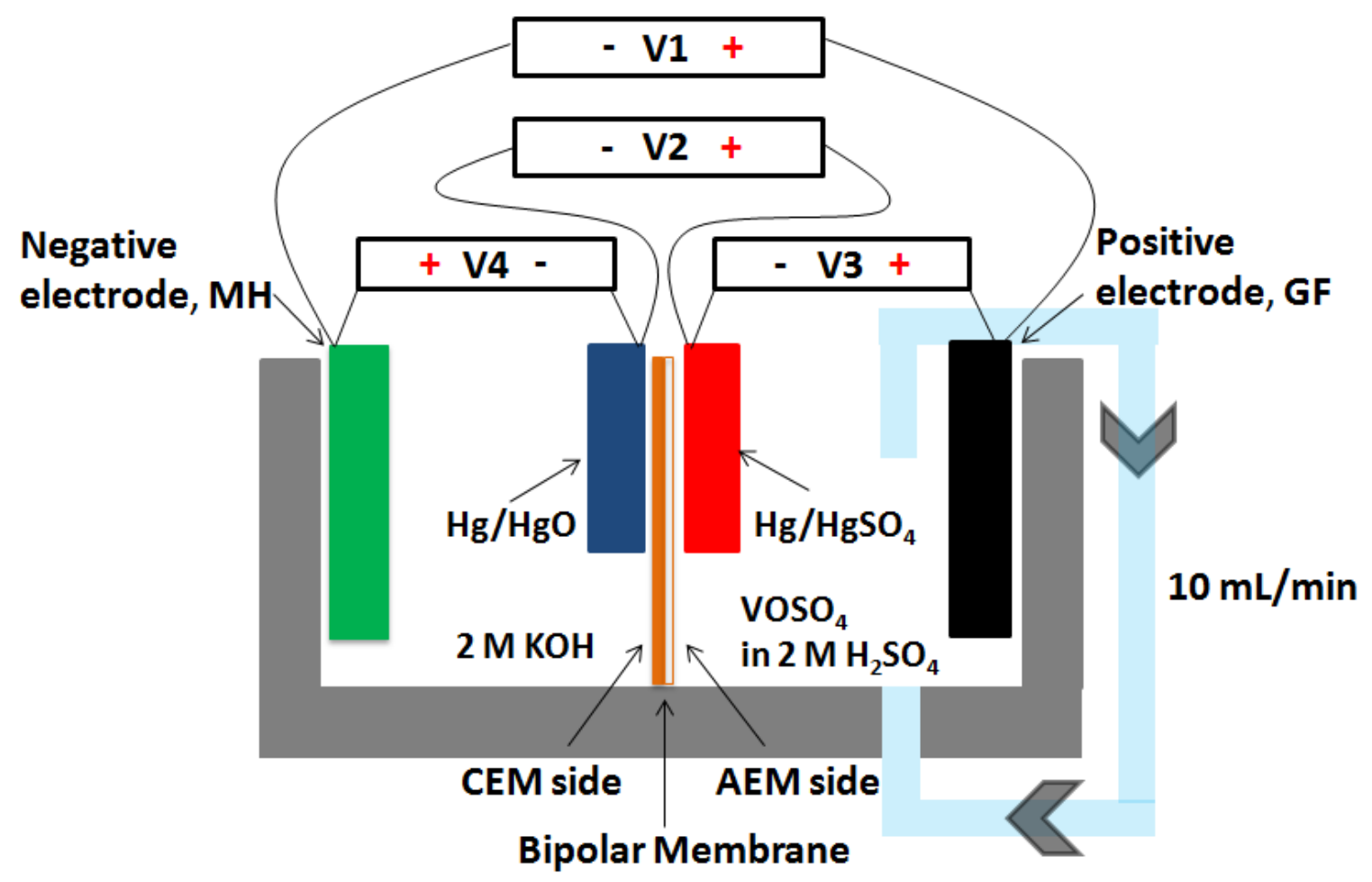

Fig. 1. Schematic drawing of the V-MH hybrid system with positive electrolyte flow. V1: Potential difference between GF electrode and $\mathrm{MH}_{\mathrm{x}} / \mathrm{MH}_{\mathrm{x}-1}$ electrode or overall cell potential. V1 $=\phi_{\text {positive }}-\phi_{\text {negative }}$ V2: Potential across bipolar membrane or potential difference between reference electrodes $\mathrm{Hg} / \mathrm{Hg}_{2} \mathrm{SO}_{4}$ and $\mathrm{Hg} / \mathrm{HgO} . \mathrm{V} 2=\phi_{\mathrm{Hg} / \mathrm{Hg} 2 \mathrm{SO} 4}$ $\phi_{\mathrm{Hg} / \mathrm{HgO}}$ (Here the reference electrode $\mathrm{Hg} / \mathrm{HgO}$ in alkaline solution is arbitrarily defined as reference electrode as it is immersed into the negative chamber); V3: Potential difference between graphite felt (GF) electrode (positive electrode) and reference electrode $\left(\mathrm{Hg} / \mathrm{Hg}_{2} \mathrm{SO}_{4}\right) . \mathrm{V} 3=\phi_{\text {positive }}-\phi_{\mathrm{Hg} / \mathrm{Hg} 2 \mathrm{SO} 4} ; \mathrm{V} 4$ : Potential difference between $\mathrm{MH}_{\mathrm{x}} / \mathrm{MH}_{\mathrm{x}-1}$ electrode (negative electrode) and reference electrode $(\mathrm{Hg} / \mathrm{HgO}) . \mathrm{V} 4=\phi_{\text {negative }}-\phi_{\mathrm{Hg} / \mathrm{HgO}}$. 


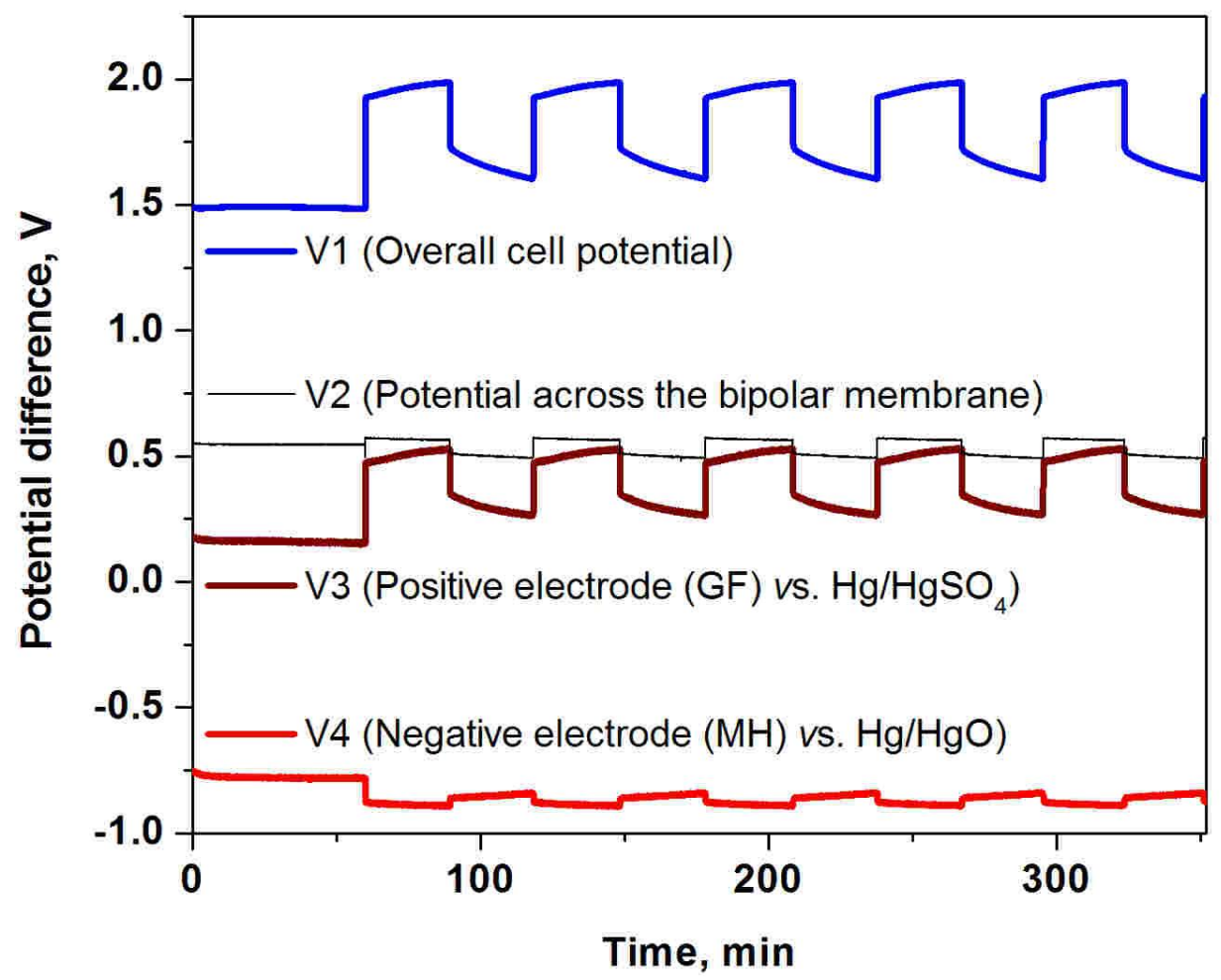

Fig. 2.5 charge and discharge cycles $\left(1^{\text {st }}-5^{\text {th }}\right)$ of V-MH battery. V1: Potential difference between GF electrode and $\mathrm{MH}_{\mathrm{x}} / \mathrm{MH}_{\mathrm{x}-1}$ electrode or overall cell potential. $\mathrm{V} 1=\phi_{\text {positive }}$ $\phi_{\text {negative; }}$ V2: Potential across bipolar membrane or potential difference between reference electrodes $\mathrm{Hg} / \mathrm{Hg}_{2} \mathrm{SO}_{4}$ and $\mathrm{Hg} / \mathrm{HgO} . \mathrm{V} 2=\phi_{\mathrm{Hg} / \mathrm{Hg} 2 \mathrm{SO} 4}-\phi_{\mathrm{Hg} / \mathrm{HgO}}$ (Here the reference electrode $\mathrm{Hg} / \mathrm{HgO}$ in alkaline solution is arbitrarily defined as reference electrode as it is immersed into the negative chamber); V3: Potential difference between graphite felt (GF) electrode (positive electrode) and reference electrode $\left(\mathrm{Hg} / \mathrm{Hg}_{2} \mathrm{SO}_{4}\right) . \mathrm{V} 3=\phi_{\text {positive }}$ $\phi_{\mathrm{Hg} / \mathrm{Hg} 2 \mathrm{SO} 4}$; V4: Potential difference between $\mathrm{MH}_{\mathrm{x}} / \mathrm{MH}_{\mathrm{x}-1}$ electrode (negative electrode) and reference electrode $(\mathrm{Hg} / \mathrm{HgO}) . \mathrm{V} 4=\phi_{\text {negative }}-\phi_{\mathrm{Hg} / \mathrm{HgO}}$. 


\section{Table Captions}

Table 1. Comparison of V-MH and VRF batteries in terms of average voltage, coulomb, and energy efficiencies. 
Table 1. Comparison of V-MH and VRF batteries in terms of average voltage, coulomb, and energy efficiencies.

\begin{tabular}{lcccc} 
Battery type & $\begin{array}{l}\text { Nominal } \\
\text { voltage, V }\end{array}$ & $\begin{array}{l}\text { Voltage } \\
\text { efficiency }\end{array}$, \% & $\begin{array}{l}\text { Coulombic } \\
\text { efficiency }{ }^{\mathrm{c}}, \%\end{array}$ & $\begin{array}{l}\text { Energy } \\
\text { efficiency }{ }^{\mathrm{d}}, \%\end{array}$ \\
\hline V-MH & 1.65 & 83.8 & 97 & 81.3 \\
VRF[8] & 1.25 & $62-73$ & $80-98$ & $66-75$
\end{tabular}

${ }^{\mathrm{b}}$ Voltage efficiency: $\eta_{V}=V_{\text {discharge }} / V_{\text {charge }}$

${ }^{\mathrm{c}}$ Coulomb/charge efficiency: $\eta_{c}=Q_{\text {discharge }} / Q_{\text {charge }}=\left(I t_{\text {discharge }}\right) /\left(I_{\text {charge }}\right)$

${ }^{\mathrm{d}}$ Energy efficiency: $\eta_{P}=E_{\text {discharge }} / E_{\text {charge }}=\left(V_{\text {discharge }} I t_{\text {discharge }}\right) /\left(V_{\text {charge }} I t_{\text {charge }}\right)$ 